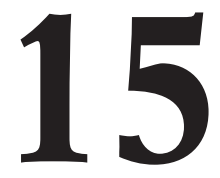

\title{
GAMIFICATION EXPERIENCE IN THE SUBJECT OF DESCRIPTIVE GEOMETRY FOR ARCHITECTURE
}

(EXPERIENCIA DE GAMIFICACIÓN EN LA ASIGNATURA DE GEOMETRÍA DESCRIPTIVA PARA LA ARQUITECTURA)

Antonio Álvaro-Tordesillas

Marta Alonso-Rodríguez

Irene Poza-Casado

Noelia Galván-Desvaux

Universidad de Valladolid

DOI: $10.5944 / e d u c X X 1.23591$

\section{How to reference this article/ Cómo referenciar este artículo:}

Álvaro-Tordesillas, A.; Alonso-Rodríguez, M.; Poza-Casado, I., \& Galván-Desvaux, N. (2020). Gamification experience in the subject of Descriptive Geometry for Architecture. Educación XX1, 23(1), 373-408, doi: 10.5944/educXX1.23591

Álvaro-Tordesillas, A.; Alonso-Rodríguez, M.; Poza-Casado, I., y Galván-Desvaux, N. (2020). Experiencia de gamificación en la asignatura de geometría descriptiva para la arquitectura. Educación XX1, 23(1), 373-408, doi: 10.5944/educXX1.23591

\section{ABSTRACT}

The hasty changes in the curricula that have occurred in recent years in the School of Architecture of University of Valladolid have generated some problems in the subject of Descriptive Geometry that have been added to others that had been ongoing for many years. A Teaching Innovation Project (TIP) seeks to provide a solution to the problems raised with new methods of teaching inside and outside the classroom and greater interaction between the students and the professor. This way, geometry is no longer something abstract, unrelated to the professional practice of the 
architect. Thereby, it is intended to structure a new subject that provides students not only with graphic and spatial techniques but also with teamwork, cooperation, training, sufficiency and autonomy resources that help them in the development of their future career. In order to carry out this new methodology for teaching, a course based on gamification has been designed, which allows the students to focus on the subject from a more playful point of view with the aim of motivating and involving them. Based on a three-year experience of comparative work between the traditional and the proposed systems, the conclusions obtained with regards to the withdrawal rate, academic performance and perception of the teaching method are presented in this paper. The incorporation of techniques based on games had a motivating effect on the students, who discovered a way of learning by playing what they previously perceived as a tedious subject.

\section{KEYWORDS}

Cooperative learning; teaching methods; educational games; motivation techniques; instructional innovation; postsecondary education.

\section{RESUMEN}

Los apresurados cambios en los planes de estudio que se han sucedido en los últimos años en la ETS Arquitectura de la Universidad de Valladolid, han generado algunos problemas en la asignatura de Geometría Descriptiva que se han unido a otros que venía padeciendo desde muchos años atrás. A través de un Proyecto de Innovación Docente (PID), se busca dar solución a los problemas planteados mediante nuevos métodos de enseñanza dentro y fuera del aula y a una mayor interacción entre alumnos y profesor, de modo que la geometría no sea algo abstracto, ajeno al ejercicio profesional del arquitecto. Con todo ello, se pretende estructurar una nueva asignatura que capacite al alumno de técnicas y recursos no solo gráficos y espaciales, sino de trabajo en equipo, cooperación, capacitación, suficiencia y autonomía que le ayuden en el desarrollo de su futura profesión. Para llevar a cabo esta nueva estructura de la docencia se ha diseñado un curso basado en la gamificación, que permite a los alumnos enfocar la asignatura desde un punto de vista más lúdico, con el objetivo de motivarlos e involucrarlos. A partir de una experiencia basada en tres años de trabajo comparativo entre los sistemas tradicionales y los propuestos, en este trabajo presentamos las conclusiones obtenidas de este nuevo método en lo que respecta a la tasa de abandono, rendimiento académico y percepción del método de enseñanza por parte de los alumnos. La incorporación de técnicas basadas en el juego 
ha tenido un efecto motivador para los alumnos, que descubren una manera de aprender jugando lo que antes percibían como una asignatura tediosa.

\section{PALABRAS CLAVE}

Aprendizaje en grupo; método de enseñanza; innovación pedagógica; juego educativo; motivación; enseñanza post-secundaria.

\section{INTRODUCTION}

\section{State of the art: the need for a renovation}

The hasty modification of the curricula of the Bachelor of Architecture during the last years has meant that in the Schools of Architecture of Spain, the subject of Descriptive Geometry has undergone a series of transformations.

We were facing an adverse environment determined by general difficulties for the set of subjects of the degree, and specific ones for the subject:

- An insufficient level of access to the Bachelor of Architecture, motivated by the low demand for these studies. This implied groups of students increasingly heterogeneous with low academic and critical level. Thomas and Cornuel (Thomas \& Cornuel, 2012) refer to 'Massification', a concept which refers to the enrolment of students beyond the levels required to repopulate academia. This inevitably leads to larger and more diverse classes of students.

- A gradual reduction of hours/credits that the new plans determine for the graphic subjects of the first year, all of them propaedeutic and necessary in the education of an architect. This reduction has only meant so far, the immediate and unreflective elimination of some of the lessons of the program, but never a remodelling, rethinking or at least updating of the subject.

- A division of the annual subject into two semester-long ones with a marked difference of credits for each semester, which represents a real challenge when designing a theme of the course and its development in a coherent way. 
- A high number of students in the groups, which exceeded forty, dedicated to passive teaching based on magisterial lessons.

- The statism of the subject. It had been taught for more than twentyfive years in the same way, repeating even the same exercises year after year. The reasons for this regard transcend the purpose of this paper.

Descriptive Geometry (DG) is the discipline responsible for representing in two dimensions all the three-dimensional bodies of nature so that they can be rigorously determined. Thus, it is possible "to recognize by means of an exact description the forms of the bodies and to deduce all the truths that result, either of their forms or of their respective positions" (Monge, 1998).

The first-year students of Architecture were frightened by a stereotyped subject, arid and excessively complex because of the abstraction required for the spatial thinking. As a consequence, students became intimidated, discouraged and quickly disinterested. They felt that this subject was useless, very difficult and it would only be an obstacle to save to become architects. It was a bad start. Students were unmotivated and, of course, little involved with their learning. What appears certain is that with the method that had been previously applied, there was little to do in order to change this situation.

There are different ways to improve the implication of the students with the subject:

- By finding the tools that help them to see and understand those objects in space (such as those offered by some computer applications) and their flat projections.

- By expanding the students' connection to the subject (the professor, the theme of the course and the rest of their classmates) through the use of virtual desks, not limited only to the class time.

- By approaching the abstraction of geometry per se to the specific reality of architecture.

\section{The motivation for learning: the centre of change}

In the pedagogical field, motivation means providing motives; that is, stimulating the way of learning. The students invest their attention and effort in certain matters (Santamaría González, 2013). Without expecting 
a classification of the different approaches or dimensions that classical pedagogy adopts to explain motivation (Díaz Barriga Arceo, \& Hernández Rojas, 2010), it is possible to extract some common realities from all of them. That is, motivation feeds on learned behaviors, impulses and reinforcements. It is built on the need of freedom, self-esteem, competence, the ability of the student's choice. Motivation is reinforced by the active search for meaning and satisfaction with regard to what is done. Obviously, it needs sociocultural support to develop.

Based on these realities, the priority objective was to involve the students hoping that they felt the intrinsic impulse to do things for themselves, for pleasure, for fun, because they felt better doing them. In this sense, Daniel Pink (2009) identifies three keys:

- The autonomy that allows students to choose which project to devote part of their time. Autonomy makes it possible to accommodate the fact that not everyone learns in the same way. In accordance with the principle of multiple intelligences (Gardner, 1983), autonomy allows the students to be guided towards a variety of contents in different formats: books, magazines, multimedia content, blogs, social networks, etc. In the same way, the students document what they have learned freely, with an oral presentation to their classmates, a post on a blog, or projecting a video (Viñas, 2011).

- The mastery that makes the students flow, in allusion to the term of Csíkszentmihályi (1990), when there is an affinity between the activity to be performed and their talent. Mastery refers to our desire to improve our skills, to progress and to be more and more capable.

- Purpose. Students work best when they understand the purpose behind a classroom project and especially see its usefulness within their professional future.

\section{A teaching innovation project (TIP) for Descriptive Geometry}

During the academic years 2015-2016, 2016-2017 and 2017-2018 a TIP was designed and developed, which was committed to face and try to solve the difficulties described above. To this end, four clear objectives were set:

- Involve the students with the subject. That is, to revitalize the pedagogical fact. Involving the students means making them participate in the development of the subject and making them part of the process, and essential for their classmates. Involving 
means changing the method of teaching so that the students find an attractive way of learning the subject. The method was modified to adapt to a structure and procedure based on gamification, defined as the application of typical elements of game playing (rules of play, point scoring, competition with others) to other areas of activity, like education, specifically to engage users in problem-solving.

- Introduce new technologies in the classroom and use them as a teaching vehicle for DG. This is possible today both to analyze figures in space (relationships and relative positions, proportions, etc.), as well as to achieve connectivity, interaction and quick and effective communication between the professor and the student and among students. For the first objective, the SketchUp® software was introduced, which allowed and facilitated three-dimensional thinking and development. For the second objective, social media were used (Facebook, Moodle) which hosted the theme of the course, exercises and enabled a forum to maintain this contact.

- Redesign the program of the subject, necessarily accompanied by the two previous objectives. It was possible to spend time in a more precise way to each lesson and modify or remove those that were susceptible to a revision. On the other hand, the new theme of the course addressed more pragmatic aspects, with immediate applications, bringing closer geometry to tangible architecture. All this had to be accompanied by an adaptation and reformulation of the exercises, considering them not only within a new methodology based on gamification but within a continuous evaluation of the course. These exercises had to train the students in the development of skills for three-dimensional ideation and thought.

- Define a continuous evaluation, eliminating definitively the classic system of a unique test. This means the design of different types of exercises, with its specific evaluation system. The students knew from the beginning what types of exercises there were, what goals they had to overcome, what grade each one contributed to their final grade, as well as how much time is provided to complete them or when to do them. The continued attention to the work and results of the students had to be enough to evaluate them.

\section{Review of the literature on gamification}

Gamification is presented in the literature as a pedagogical innovation that may increase student engagement and enhance learning. There are 
numerous experiences on the use of gamification in the classroom, as well as reviews of the literature about it (Buckley, Doyle, \& Doyle, 2017; Hamari, Koivisto, \& Sarsa, 2014; Mora, Riera, Gonzalez, \& Arnedo-Moreno, 2015; Nah, Zeng, Telaprolu, Ayyappa, \& Eschenbrenner, 2014). Gamification has been defined as a process of enhancing services with affordances in order to invoke gameful experiences and further behavioural outcomes (Hamari, 2013). It is a new and powerful strategy to influence and motivate groups of people (Cheong, Cheong, \& Filippou, 2013; Deterding, Khaled, Nacke, \& Dixon, 2011; Domínguez, et al., 2013; Fitz-Walter, Johnson, Wyeth, Tjondronegoro, \& Scott-Parker, 2017; Lee \& Hammer, 2011; Lessel, Altmeyer, \& Krüger, 2015).

In defining gamification, Huotari and Hamari (Huotari \& Hamari, 2012) highlight the role of gamification in invoking the same psychological experiences as games (generally) do. Deterding, et al. (Deterding, Dixon, Khaled, \& Nacke, 2011), on the other hand, emphasize that the affordances implemented in gamification have to be the same as the ones used in games, regardless of the outcomes: "(...) we propose a definition of "gamification" as the use of game design elements in non-game contexts". However, Hamari et al. (Hamari \& Koivisto, 2014) wonder which affordances are unique to games as well as which psychological outcomes can be strictly considered to stem from games.

Thus, gamification can be defined as the use of game mechanics in non-ludic environments and applications in order to enhance motivation, concentration, effort, loyalty and other positive values common to all games. These mechanics also seem adequate in the environment in which we currently live: a videogame environment and social relationships through mobile devices. In this environment, the average university student profile has a lot in common with the average profile of the gamer ( $\mathrm{Zhu}$, Wang, \& Zyda, 2018). Students belong to a new generation group (Elam, Stratton, \& Gibson, 2007; Howe \& Strauss, 2003; Ramos-Salazar \& Diego-Medrano, 2019) referred as "Generation Y", designed by some as "digital natives" (Prensky, 2007), exposed to information technology from birth. Prensky believes that Digital Generation can think faster and be multitask exactly because of practising computer games and using mobiles and other gadgets. For them, all these technologies always existed and are used as something that was always part of their lives (Johnson, Smith, Willis, Levine, \& Haywood, 2011). 


\section{METHODOLOGY AND MATERIALS: THE GAMIFICATION FOR THE ORGANIZATION OF THE COURSE}

From the aforementioned objectives, the design of a course based on gamification was proposed.

\section{Guidelines for the course design}

Gamification is already a novel concept in the higher education domain. While the application of gamification in education is still an emerging trend (Dicheva, Dichev, Agre, \& Angelova, 2015), its proponents suggest that it can be employed to enhance students engagement and prompt learning (Buckley, et al., 2017). In fact, Hamari, et al. (2014), in their study on Literature Review of Empirical Studies on Gamification, conclude how the gamification does work. Robson, et al. (2015) explain why gamification works and present five summary guidelines to show how gamified experiences can be created.

At the same time, Buckley, et al. (2017) identify some factors that need to be carefully considered for other professors in designing and implementing gamified learning interventions and provide some guidelines. Among them, it refers to the class size, what other teaching and learning approaches are being deployed to suit different learner types, the nature, and visibility of rewards and, of course, the key learning outcomes that the educator wants students to achieve.

The proposed gamified course of DG was designed taking into account these ideas. A class dynamic based on game mechanics can be constructed supported in them and in the aforementioned theories. The following premises-strategies for its design were employed:

- The course and activities had to be a challenge. For that purpose, it could not be too simple, because the student would be bored and put an end to the game before achieving the desired goal, or too complicated, because setting the bar too high ends up producing frustration or stress in the student.

- The goals should be designed as clearly as possible. Thus, the student would perceive them easily and identify that the objectives are achievable.

- It was necessary for the students to receive positive feedback that would help them identify their achievements and their defeats. This was materialized in both a continuous evaluation system and 
ANTONIO ÁLVARO-TORDESILLAS, MARTA ALONSO-RODRÍGUEZ, IRENE POZA-CASADO,

a ranking (leaderboard), which is key of the model of motivated learning fostered by competitiveness with respect to the learning of others, making it social (Festinger, 1954).

The students, used to understanding that the result of their work was relatively uncertain, had to feel that their final grade was conditioned by their actions in a more direct way. To this end, the students knew from the first day the options they had in order to reach the grades that would allow them to achieve the objectives. The students knew week after week the grade reached so that they could know when they accomplished the minimum requirements defined by the program of the subject and how much time they had left to do it (Beza, 2011; Burke, 2014).

\section{Design of the gamified course of DG: concrete proposal}

In this experience in which gamification was applied for the first time in a university graphic subject, a structure for the course (framework) of the PBLs type was proposed: Points, Badges and Leaderboards. This methodological proposal was aimed at motivating the students, promoting competitiveness (Huang \& Hew, 2015), and offering instant feedback to them in such a way that they knew at all times their progress and final grade (Erenli, 2013). It is important to note that, in this way, this framework introduced a single gamification element (PBLs), rather than a large set of different mechanisms, so that the students did not have to "study" a new "subject" that were the rules of the game, as suggested by Hamari (Hamari, 2017). Points refer to tokens that can be collected by users, which can be used as status indicators or to spend on virtual goods or gifting. Badges refer to trophies that appear as icons or logos on a webpage that signify a user's accomplishments of a particular activity such as completion of a Project Khan Academy has a badging system (Thompson, 2011)—. Leaderboards refer to high-grade tables that indicate an individual's performance compared with other users (Domínguez, et al., 2013).

In this design, points were awarded for each of the exercises developed throughout the course. Four badges could be obtained and focused on the weekly exercises and the results of the tests. They were also cumulative and each one rewarded adding 0.05 points to the final grade:

- By correctly finishing the weekly exercise among the first three students.

— For being among the three best results of the weekly test. 
- For drawing the sheet outstandingly (cleanliness and precision).

- For proposing new exercises.

The leaderboard was incorporated, along with a progress bar where students could quickly see their position among their classmates. PBLs also provided the sought feedback, which was regarded as an important antecedent to flow and engagement (Csikszentmihalyi, 1990), and this has also been reported to be strongly linked to gamification (Hamari \& Koivisto, 2014).

In order to measure the results, the gamified course was held in the second semester of the course, following the traditional methodology in the first semester. In this way, this first semester was understood as 'control' with respect to the second, being able to compare the results. Both semesters had a similar difficulty for the students, proven by the academic results obtained in previous years.

One of the advantages of having two semesters articulated in a few weeks is that the students obtained an overview of the semester, evaluating it globally and understanding the long-term importance of their weekly decisions. An annual course would probably mean a loss of perspective and effectiveness, especially at this early stage of the university degree.

Thus, the gamified semester was structured according to four blocks: weekly tests, weekly exercises, semester-long exercises, and a final test. Each block took advantage of the aforementioned most appropriate tools, and each one with a specific contribution in the final note (Nieto Martín, 2000).

a) Weekly test: every week the students had to study at home the planned course topics. For that end, resources were provided in various formats (uploaded to Moodle), depending on the specific content: videos, texts, three-dimensional models, etc. We were aware that these files could not be too big, which was one of the most important variables when implementing gamification in the course. Sometimes, the content was split among the students (in groups of four). Each student became a part and had to explain it to other classmates, according to the dynamics of the Aronson puzzle (Aronson, Blaney, Stephin, Sikes, \& Snapp, 1978). This tool increased competences of the students, as well as their knowledge in a specific subject, through a dynamic and functional methodology (Martínez Ramón \& Gómez Barba, 2010). 
ANTONIO ÁLVARO-TORDESILLAS, MARTA ALONSO-RODRÍGUEZ, IRENE POZA-CASADO,

The contents studied at home were discussed in class to review it among all the students before doing the test. The inclusion of a digital board in the classroom, together with the chalk one, was enough to ensure that these debates were not unidirectional, and students adopted an active position.

The tests were carried out in two ways: a) on paper, drawing the solutions; b) digitally, according to the game-contest model Kahoot mobile application (https://kahoot.com/what-is-kahoot/). Kahoot is a good tool for classroom activities that improve students' participation, fostering positive relationships between the professor and the students, and among students. The result, as Cerro points out (Cerro Gómez, 2015), was also a higher rate of class attendance, which made Kahoot an interesting tool for students, who perceived it as a game and not an evaluation system (Fernández-Mesa, OlmosPeñuela, Alegre, \& Alegre, 2016; Inge, 2014; Rodríguez-Fernández, 2017).

The three best students were awarded badges. Each test was evaluated on ten points, and they represented $25 \%$ of the final grade of the course.

b) Weekly exercise in class: it was focused on the immediate application of the contents studied, to be done individually but in which all the participants of the class can collaborate (classmates and professor). Each of these exercises was evaluated on ten points according to a rubric designed for this purpose (Appendix A). These represented $25 \%$ of the final grade. Badges could also be awarded to the first three students who finished the exercise correctly, to the one who drew the best and who proposed a new exercise.

c) Semester-long exercise: this was a work to be carried out in teams, addressing a practical topic based on the theoretical knowledge developed weekly. As an example of one of the courses, it consisted of imagining, drawing and building an object that, when repeated and joined to other similar pieces, would form a piece of furniture.

Thus, the students had to complete four levels that would provide recognition in overcoming milestones; namely (figure 1):

- Design and geometric description of the polyhedral

- Digital three-dimensional modelling 
- Development of a model of the prototype

- Physical construction at real size

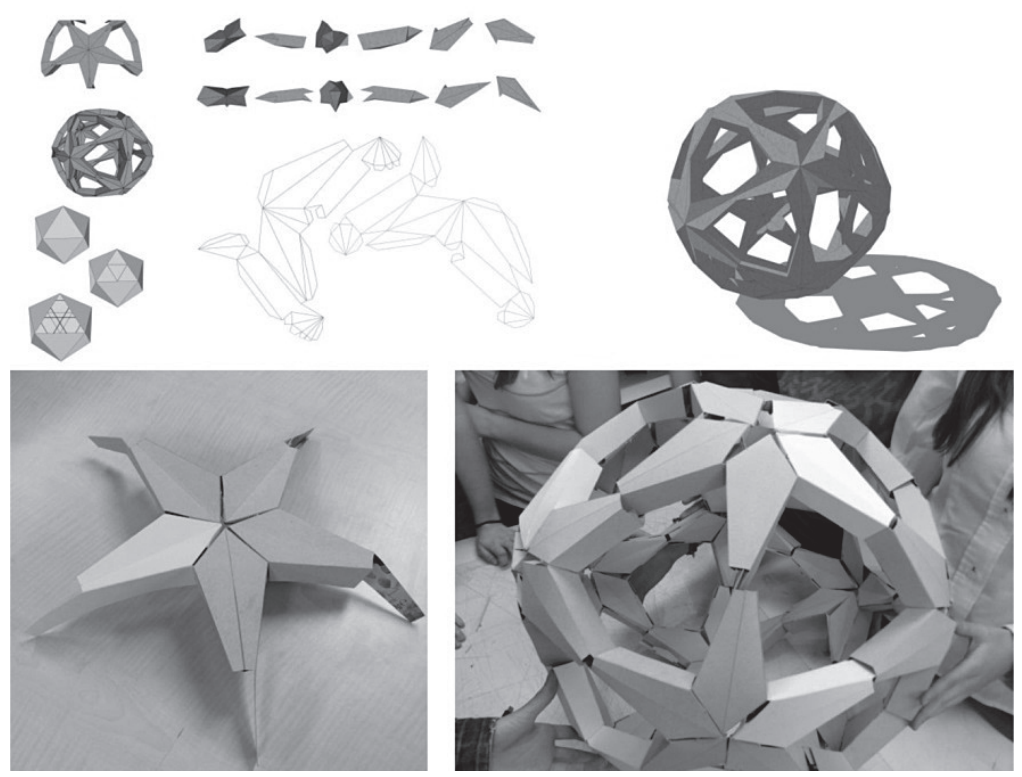

Fig. 1. Four levels in the execution of the semester-long exercise. In the example, the students have designed a lamp from the geometric transformation of an icosahedron

The three keys enunciated by Daniel Pink (2009) were proposed with this exercise and they were put into practice by the strategies of Csíkszentmihályi (1990). The purpose of the exercise and the implied learning was easily apprehended by the students if it was properly contextualized. Such a project made them feel like future designers, full of creativity, but it also made them aware of the imperative need to learn geometry and the ways of expressing it (projection systems, three-dimensional models, etc.) On the other hand, the possibility of choosing and deciding what piece of furniture they wanted to develop had a lot to do with the autonomy of the student. They were even given the opportunity to change the exercise. For instance, some of them proposed to work in a construction game, a three-dimensional puzzle, etc. In this sense, they were free to choose what and how to study to develop the furniture, as well as how to explain it to their colleagues, so that both the professor and they could intervene and evaluate (mastery).

The last level of the game acted at the same time as a prize. The best works that had completed all the previous levels were 
ANTONIO ÁLVARO-TORDESILLAS, MARTA ALONSO-RODRÍGUEZ, IRENE POZA-CASADO,

built in real size and exhibited in the main hall of the School of Architecture.

This exercise gave them up to ten points, depending on how they performed in each of the four phases. Its value in the final grade was $25 \%$.

d) Final test: it was constituted by three exercises similar to those carried out in the class and it took place at the end of the semester. Ten points could also be reached with this exercise, whose value was also $25 \%$.

A leaderboard, a table where each student could see the grade in each exercise, the total sum and the final grade (table 1), was published each week in the class. This way the students were able to see the cumulative grade, what grade they still had to reach and figure the strategy in time to achieve it. In addition, the introduction of a progress bar in the purest videogame style became an extremely powerful tool (graph 1).

Table 1

Grades and Leaderboard template. Grades board of one group in week five. It can be seen by colour columns, from left to right: weekly practices, weekly test, semester practice, and final test. At right the students ranking. The name of the students has been omitted.

\begin{tabular}{|c|c|c|c|c|c|c|c|c|c|c|c|c|c|c|c|c|c|c|c|c|c|c|c|}
\hline \multicolumn{18}{|c|}{$\begin{array}{l}\text { DESCRIPTIVE GEOMETRY (2nd SEMESTER) } \\
\text { GROUP } 1\end{array}$} & \multirow{2}{*}{ 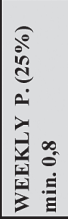 } & \multirow{2}{*}{ 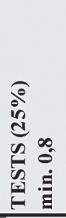 } & \multirow{2}{*}{ 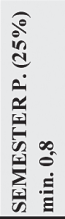 } & \multirow{2}{*}{ 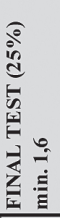 } & \multirow[b]{2}{*}{ 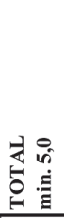 } & \multirow{2}{*}{ 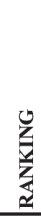 } \\
\hline & \begin{tabular}{|l|l|}
1 & 2 \\
\end{tabular} & 3 & 4 & 5 & \begin{tabular}{l|l}
6 & 7 \\
\end{tabular} & \begin{tabular}{l|l|l}
7 & 8 & 9 \\
\end{tabular} & 10 & 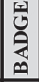 & & 23 & 4 & & $\begin{array}{l}2 \\
\text { 息 } \\
0 \\
0 \\
0\end{array}$ & 1 & 2 & \begin{tabular}{l|l|}
1 & 2 \\
\end{tabular} & $\begin{array}{l}2 \\
2 \\
\end{array}$ & & & & & & \\
\hline Student 1 & $\sqrt{4}$ & 8 & 8 & 8 & & & & & 3 & \begin{tabular}{l|l}
6 & 6 \\
\end{tabular} & 7 & & & 4 & & & & 0,7 & 0,7 & 0,5 & 0,0 & 1,9 & 17 \\
\hline Student 2 & \begin{tabular}{|l|l|}
7 & 7 \\
\end{tabular} & 8 & 7 & 6 & & & & 1 & 6 & \begin{tabular}{l|l|}
4 & 7 \\
\end{tabular} & 5 & & & 9 & & & & 0,9 & 0,7 & 1,1 & 0,0 & 2,7 & 5 \\
\hline Student 3 & \begin{tabular}{|l|l|}
6 & 6 \\
\end{tabular} & 5 & 6 & 6 & & & & & 5 & \begin{tabular}{l|l|}
5 & 5 \\
\end{tabular} & 4 & & 1 & 4 & & & & 0,8 & 0,6 & 0,5 & 0,0 & 1,9 & 16 \\
\hline Student 4 & \begin{tabular}{|l|l|}
8 & 7 \\
\end{tabular} & 8 & 1 & 8 & & & & 4 & 3 & \begin{tabular}{|l|l|}
3 & 9 \\
\end{tabular} & 6 & & 2 & 7 & & & & 1,2 & 0,7 & 0,9 & 0,0 & 2,8 & 3 \\
\hline Student 5 & \begin{tabular}{|l|l|}
5 & 2 \\
\end{tabular} & & & & & & & & 3 & 2 & & & & 1 & & & & 0,2 & 0,1 & 0,1 & 0,0 & 0,4 & 20 \\
\hline Student 6 & \begin{tabular}{|l|l}
7 & 7 \\
\end{tabular} & 10 & 4 & 9 & & & & 3 & 8 & \begin{tabular}{l|l|}
3 & 4 \\
\end{tabular} & 5 & & & 7 & & & & 1,1 & 0,6 & 0,9 & 0,0 & 2,6 & 8 \\
\hline Student 7 & 4 & 7 & 4 & 9 & & & & 1 & & 67 & 6 & & 1 & 8 & & & & 0,7 & 0,6 & 1,0 & 0,0 & 2,3 & 12 \\
\hline Student 8 & 82 & 8 & 9 & 9 & & & & 3 & 1 & \begin{tabular}{l|l|}
6 & 8 \\
\end{tabular} & 5 & & 1 & 8 & & & & 1,1 & 0,7 & 1,0 & 0,0 & 2,7 & 6 \\
\hline Student 9 & \begin{tabular}{|l|l}
9 & 7 \\
\end{tabular} & 9 & 5 & 2 & & & & 1 & 5 & \begin{tabular}{l|l}
8 & 5 \\
\end{tabular} & 5 & & 1 & 8 & & & & 0,9 & 0,8 & 1,0 & 0,0 & 2,6 & 7 \\
\hline Student 10 & \begin{tabular}{|l|l}
8 & 7 \\
\end{tabular} & 9 & 8 & 8 & & & & 3 & 2 & $\begin{array}{ll}65 \\
\end{array}$ & 6 & & 1 & 10 & & & & 1,2 & 0,6 & 1,3 & 0,0 & 3,0 & 1 \\
\hline Student 11 & \begin{tabular}{|l|l}
9 & 7 \\
\end{tabular} & 8 & 4 & 8 & & & & & 2 & 65 & 5 & & & 4 & & & & 0,9 & 0,5 & 0,5 & 0,0 & 1,9 & 15 \\
\hline Student 12 & \begin{tabular}{|l|l}
67 \\
\end{tabular} & & & & & & & & 4 & 4 & & & & 1 & & & & 0,3 & 0,2 & 0,1 & 0,0 & 0,7 & 19 \\
\hline Student 13 & \begin{tabular}{|l|l}
7 & 7 \\
\end{tabular} & 8 & 6 & 8 & & & & & 2 & \begin{tabular}{l|l}
3 & 5 \\
\end{tabular} & 5 & & & 9 & & & & 0,9 & 0,5 & 1,1 & 0,0 & 2,5 & 10 \\
\hline Student 14 & \begin{tabular}{|l|l|}
7 & 6 \\
\end{tabular} & 8 & 6 & 7 & & & & 1 & 7 & \begin{tabular}{c|c|}
5 & 5 \\
\end{tabular} & 5 & & 1 & 3 & & & & 0,9 & 0,7 & 0,4 & 0,0 & 2,0 & 13 \\
\hline Student 15 & \begin{tabular}{|l|l|}
7 & 3 \\
\end{tabular} & 4 & 4 & 5 & & & & & 2 & $\begin{array}{ll}4 & 3 \\
\end{array}$ & 6 & & & 4 & & & & 0,6 & 0,5 & 0,5 & 0,0 & 1,5 & 18 \\
\hline Student 16 & \begin{tabular}{|l|l|}
9 & 8 \\
\end{tabular} & 9 & 6 & 2 & & & & 2 & 7 & \begin{tabular}{l|l}
8 & 5 \\
\end{tabular} & 5 & & 1 & 8 & & & & 1,0 & 0,8 & 1,0 & 0,0 & 2,8 & 4 \\
\hline Student 17 & \begin{tabular}{|l|l|}
7 & 8 \\
\end{tabular} & 3 & 7 & 7 & & & & 1 & 9 & \begin{tabular}{l|l|}
5 & 5 \\
\end{tabular} & 3 & & 1 & 10 & & & & 0,9 & 0,7 & 1,3 & 0,0 & 2,8 & 2 \\
\hline Student 18 & \begin{tabular}{|l|l|}
5 & 5 \\
\end{tabular} & 5 & 8 & & & & & & 6 & \begin{tabular}{|l|l|}
3 & 5 \\
\end{tabular} & 4 & & & 6 & & & & 0,7 & 0,6 & 0,8 & 0,0 & 2,0 & 14 \\
\hline Student 19 & \begin{tabular}{|l|l|}
7 & 5 \\
\end{tabular} & 8 & & 5 & & & & 2 & 7 & \begin{tabular}{l|l}
4 & 5 \\
\end{tabular} & 5 & & 1 & 9 & & & & 0,7 & 0,7 & 1,1 & 0,0 & 2,5 & 9 \\
\hline Student 20 & \begin{tabular}{|l|l|}
9 & 7 \\
\end{tabular} & 9 & 8 & 5 & & & & 2 & 4 & \begin{tabular}{|l|l|}
3 & 5 \\
\end{tabular} & 3 & & 1 & 6 & & & & 1,1 & 0,5 & 0,8 & 0,0 & 2,3 & 11 \\
\hline
\end{tabular}




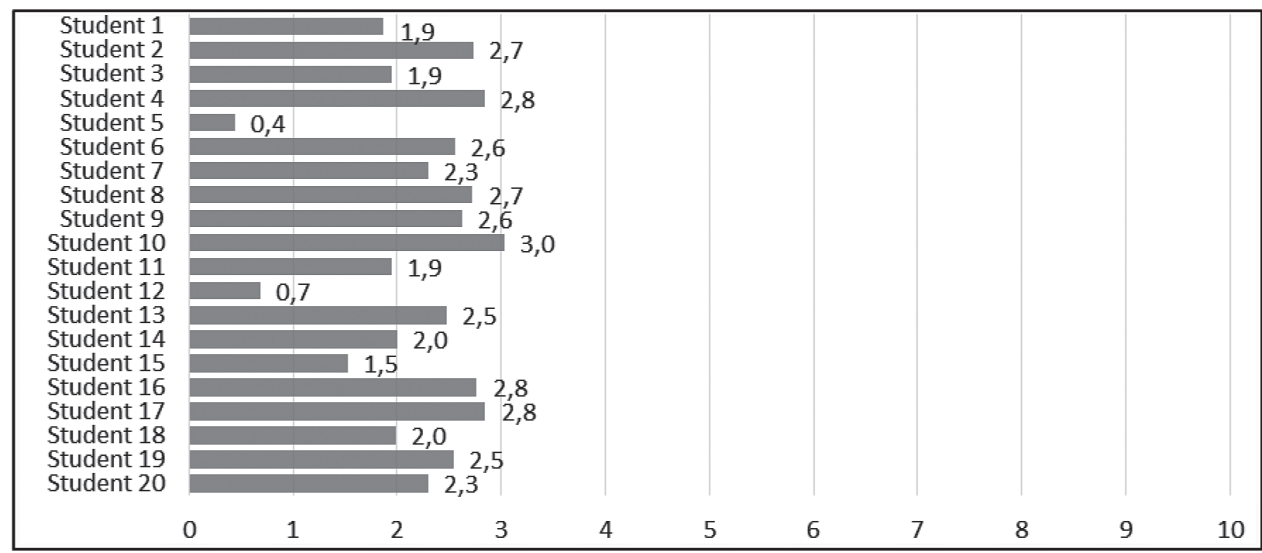

Graph 1. Progress bar for each student in week 5, where they can graphically see their grade (from 0 to 10 )

\section{Data: sample and instruments}

Table 2 summarizes the samples (number of students) who took part in the study during the two semesters of the three academic years:

Table 2

Work samples Students between the ages of 18 and 19

\begin{tabular}{lccccc} 
& & \multicolumn{2}{c}{ First semester $^{\mathrm{a}}$} & \multicolumn{2}{c}{ Second semester } \\
\cline { 3 - 6 } & $\begin{array}{l}\text { Enrolled } \\
\text { students }\end{array}$ & $\begin{array}{l}\text { Who } \\
\text { complete } \\
\text { the course }\end{array}$ & $\begin{array}{l}\text { Who } \\
\text { complete } \\
\text { the survey }\end{array}$ & $\begin{array}{l}\text { Who } \\
\text { complete } \\
\text { the course }\end{array}$ & $\begin{array}{l}\text { Who } \\
\text { complete } \\
\text { the survey }\end{array}$ \\
\hline $\begin{array}{l}\text { Academic } \\
\text { year } \\
2015-2016\end{array}$ & 121 & 102 & 84 & 111 & 90 \\
$\begin{array}{l}\text { Academic } \\
\text { year }\end{array}$ & 115 & 94 & 73 & 103 & 66 \\
$\begin{array}{l}\text { 2016-2017 } \\
\begin{array}{l}\text { Academic } \\
\text { year }\end{array}\end{array}$ & 85 & 70 & 60 & 78 & 64 \\
$2017-2018$ & $\sum=321$ & & $\sum=217$ & & $\sum=220$
\end{tabular}

a. Only students who took the subject for the first time

Although the experience defined in the TIP was carried out only in the second semester of each academic year, the results obtained in the first one 
needed to be understood as control data. For that reason, repeat students were eliminated from the count and included in a specific group. All students were properly informed of the structure and functioning of the course, in addition to having this information permanently in the Moodle platform.

We designed a survey to obtain the opinion of the students in the most objective possible way. The questions were gathered under three main ideas: the knowledge of the pedagogical and evaluative method that was to be followed in class, the adequacy of the workload of said method and the final evaluation of the method. The questions of both surveys can be seen at the end of this paper.

The software package used to analyze the data was the IBM SPSS Statistics; a software package used for logical batched and non-batched statistical analysis. SPSS is a widely used program for statistical analysis in social science.

\section{RESULTS AND DISCUSSION}

Firstly, the data of the academic results obtained by the students throughout the three analyzed academic years were studied. Secondly, the results of the surveys made to the students in the class were assessed. This analysis established whether the gamification methodology introduced in the classroom had an impact on the results and on the perception of the students regarding the subject or not. In order to do this, it was checked initially that there had been a similar behaviour in the three analyzed years. Then, the values obtained in each semester, that is, corresponding to the traditional and the gamification method implemented, were analyzed.

\section{Academic results}

The evaluation was the main indicator of results since they were easily computable and objectively comparable. A classification of the results obtained by the students has been made with three possible options: pass (for grades equal to or greater than 5 on the 1-10 scale), fail (grades less than 5) or withdrawal (for students who have not completed the subject). The withdrawal rate can show in a clearer way if the novelties introduced by the TIP in the Geometry course managed to involve the students in a convincing way.

In order to determine if there was a relationship between the results obtained for a total of 321 students in the three academic years (642 for both 
semesters), the Pearson Chi-squared test was performed, with a confidence level of $95 \%(\alpha=0.05)$.

Graph 2 shows the results obtained throughout the three academic years analyzed (for both semesters), with a similar distribution for each one. The number of passes predominates throughout the three years, while the number of fails does not exceed $20 \%$ and the number of withdrawals, $15 \%$ (Table 3).

The result obtained in the Chi-squared test (significance $=0.91$ ), does not allow to reject the null hypothesis $\mathrm{H}_{0}$, which implies that, statistically, there is no dependency relationship between the academic year and the result obtained by the students.

Table 3

Results obtained by academic year. Pearson Chi-squared test

\begin{tabular}{|c|c|c|c|c|c|c|}
\hline & & & \multicolumn{3}{|l|}{$\underline{\text { Result }}$} & \multirow[b]{2}{*}{ Total } \\
\hline & & & Pass & Fail & Withdrawal & \\
\hline \multirow[t]{6}{*}{ Year } & $2015-2016$ & Count & 165 & 48 & 29 & 242 \\
\hline & & $\%$ within the year & $68,2 \%$ & $19,8 \%$ & $12,0 \%$ & $100,0 \%$ \\
\hline & 2016-2017 & Count & 157 & 40 & 33 & 230 \\
\hline & & $\%$ within the year & $68,3 \%$ & $17,4 \%$ & $14,3 \%$ & $100,0 \%$ \\
\hline & $2017-2018$ & Count & 114 & 34 & 22 & 170 \\
\hline & & $\%$ within the year & $67,1 \%$ & $20,0 \%$ & $12,9 \%$ & $100,0 \%$ \\
\hline \multirow[t]{2}{*}{ Total } & & Count & 436 & 122 & 84 & 642 \\
\hline & & $\%$ within the year & $67,9 \%$ & $19,0 \%$ & $13,1 \%$ & $100,0 \%$ \\
\hline
\end{tabular}

Pearson Chi-squared $=1,02$

Significance $=0,91$ 


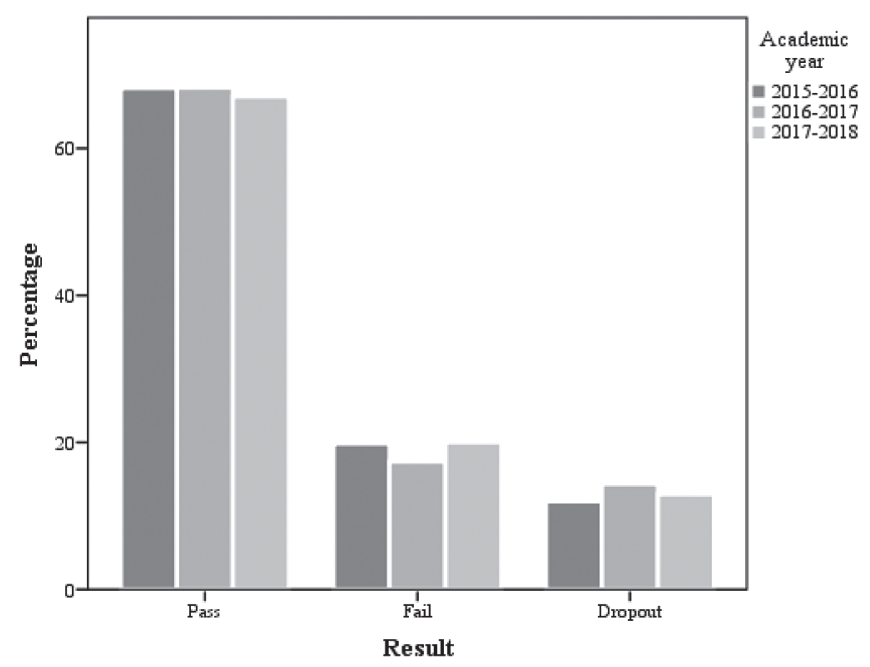

Graph 2. Percentage of results obtained by academic year

On the other hand, if the results obtained in both semesters for the three years are compared, it can be seen how, in this case, the null hypothesis is rejected when obtaining a level of significance less than 0.05 . This implies that there is a dependency relationship between the results and the semester, that is, the results obtained with a traditional methodology were different from those obtained with the gamification method introduced in the subject (graph 3).

Table 4 shows that the total number of students who pass is higher in the second semester (72.9\% compared to $62.9 \%)$ and that the withdrawal rate was considerably reduced ( $9 \%$ versus $17.1 \%$ ).

Overall it can be said that the withdrawal rate of the subject remains stable if the values per year are compared, but it varies drastically if both semesters of each year are compared. The withdrawal rate was reduced to almost half, which supports the pedagogical method of gamification tested during the second semesters of these three academic years. 
Table 4

Results obtained by semester. Pearson Chi-squared test

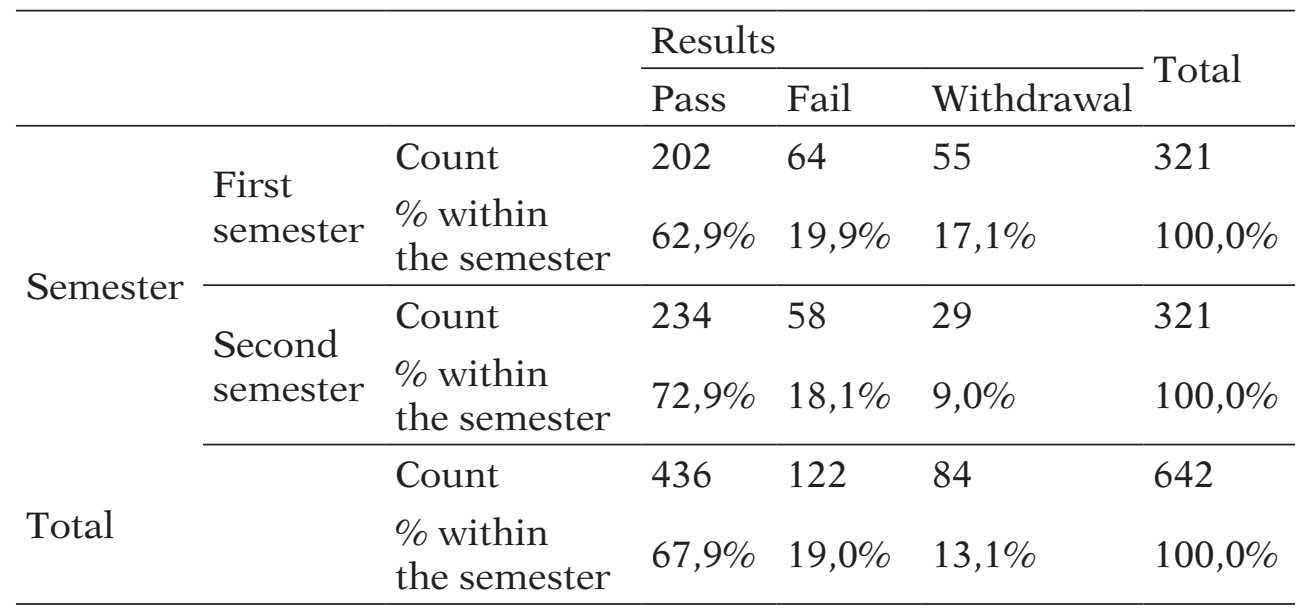

Pearson Chi-squared: 10,69

Significance: 0,01

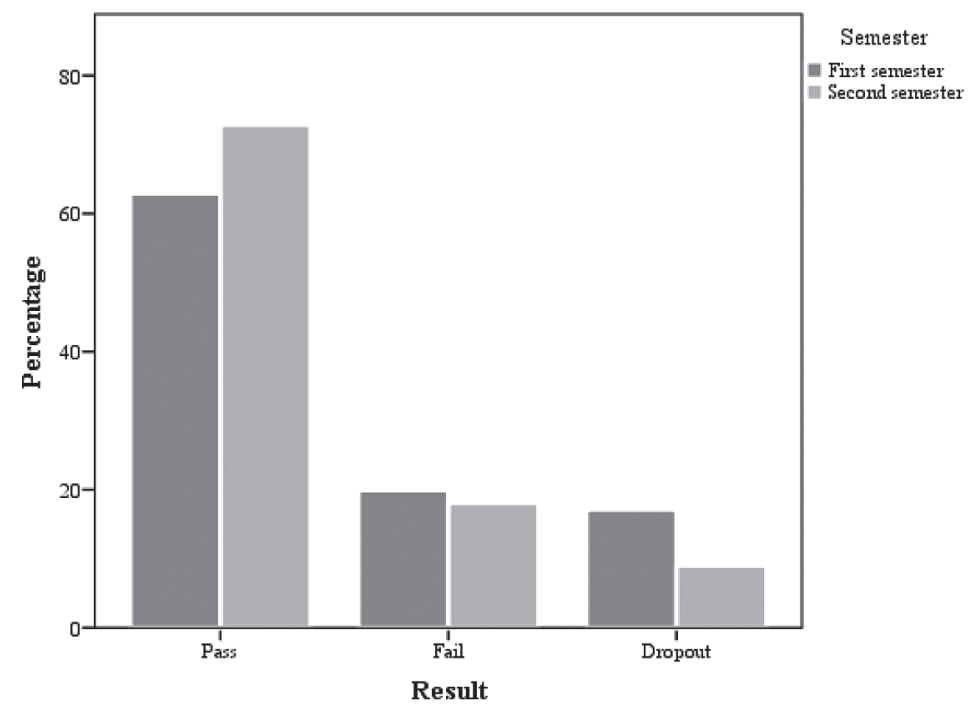

Graph 3. Percentage of results obtained by semester

This radical decrease in the withdrawal rate of the subject in the last academic years in which gamification was introduced in the classroom has led to a broader analysis including the previous 10 years, in which the methodology used was the traditional one. If over the years (between the 2005-2006 and 2014-2015 academic years) there was an average withdrawal 
ANTONIO ÁLVARO-TORDESILLAS, MARTA ALONSO-RODRÍGUEZ, IRENE POZA-CASADO,

rate of $37 \%$, in the past three academic courses it was almost a third, $13 \%$ (Graph 4).

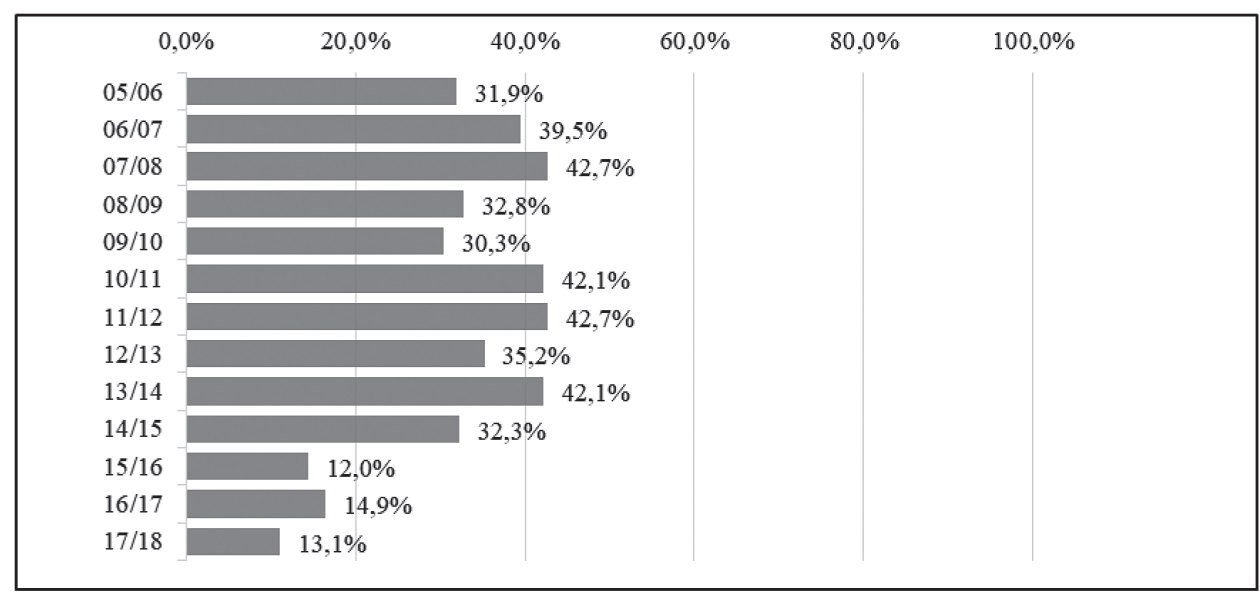

Graph 4. Percentage of students who drop out per academic year

\section{Assessment of students shown in the surveys}

The data derived from the surveys to know the students' perception of the subject (Appendix B) has been analyzed. The dependence of the evaluation in relation to the academic year and the semester (method) has been studied in the same way as it was done in the previous section. The responses to the surveys have been standardized by transformations to Z-scores and subsequently to a 1-10 scale.

First, the distribution of the variables "knowledge of the method", "workload", "assessment of the method" and "continuity in the study" were studied using the Kolmogorov-Smirnov normality test (Table 5). With significance values lower than 0.05 , it can be affirmed that the distribution is not normal, and therefore nonparametric tests have been used to analyze the relationship of the variables and the academic year and semester. Kruskal-Wallis test has been employed to know if there was a dependency relationship between the variables. 
Table 5

Analysis of the distribution of the results: Kolmogorov-Smirnov normality test

\begin{tabular}{lllll} 
& $\begin{array}{l}\text { Knowledge } \\
\text { of the } \\
\text { method }\end{array}$ & Workload & $\begin{array}{l}\text { Assessment } \\
\text { of the } \\
\text { method }\end{array}$ & $\begin{array}{l}\text { Continuity } \\
\text { in the study }\end{array}$ \\
\hline Number of samples (N) & 437 & 437 & 437 & 437 \\
\hline Test statistic & 0,26 & 0,14 & 0,07 & 0,19 \\
\hline Significance & 0,00 & 0,00 & 0,00 & 0,00
\end{tabular}

Firstly, the results of the surveys by years have been analyzed, obtaining in all cases a Chi-squared significance value greater than 0.05 , which did not allow to reject the null hypothesis $\mathrm{H}_{0}$. It can be affirmed that the perception of the students regarding the knowledge of the method, the workload, the evaluation of the method and the continuity in the study does not depend on the year (table 6).

Table 6

Results of the Kruskal-Wallis test of the surveys per academic year

\begin{tabular}{|c|c|c|c|c|c|}
\hline & $\begin{array}{l}\text { Academic } \\
\text { year }\end{array}$ & $\mathrm{N}$ & $\begin{array}{l}\text { Average } \\
\text { range }\end{array}$ & Chi-squared & Significance \\
\hline \multirow{4}{*}{$\begin{array}{l}\text { Knowledge of } \\
\text { the method }\end{array}$} & 2015-2016 & 174 & 205,50 & \multirow[t]{4}{*}{3,97} & \multirow[t]{4}{*}{0,14} \\
\hline & 2016-2017 & 139 & 231,19 & & \\
\hline & 2017-2018 & 124 & 224,27 & & \\
\hline & Total & 437 & & & \\
\hline \multirow[t]{4}{*}{ Workload } & $2015-2016$ & 174 & 221,93 & \multirow[t]{4}{*}{0,34} & \multirow[t]{4}{*}{0,84} \\
\hline & $2016-2017$ & 139 & 220,13 & & \\
\hline & $2017-2018$ & 124 & 213,62 & & \\
\hline & Total & 437 & & & \\
\hline \multirow{4}{*}{$\begin{array}{l}\text { Assessment of } \\
\text { the method }\end{array}$} & 2015-2016 & 174 & 212,05 & \multirow[t]{4}{*}{1,16} & \multirow[t]{4}{*}{0,56} \\
\hline & 2016-2017 & 139 & 227,48 & & \\
\hline & 2017-2018 & 124 & 219,25 & & \\
\hline & Total & 437 & & & \\
\hline \multirow{4}{*}{$\begin{array}{l}\text { Continuity in } \\
\text { the study }\end{array}$} & $2015-2016$ & 174 & 225,29 & \multirow[t]{4}{*}{0,81} & \multirow[t]{4}{*}{0,67} \\
\hline & $2016-2017$ & 139 & 213,41 & & \\
\hline & 2017-2018 & 124 & 216,44 & & \\
\hline & Total & 437 & & & \\
\hline
\end{tabular}

The results of the surveys per semester have been analyzed by means of the Kruskal-Wallis test. The null hypothesis must be rejected in this case, 
which indicates that the variables analyzed are dependent on the semester. In other words, the students perceived differently each method used in the course, in each semester.

Table 7 and Graph 5 show that the methodology of gamification introduced meant a greater knowledge of the method, a reduction in the workload, better assessment, as well as an improvement in the continuity in the study by the students.

Table 7

Results of the Kruskal-Wallis test of the surveys per semester

Average Chi- Significance

\begin{tabular}{|c|c|c|c|c|c|}
\hline \multirow{4}{*}{$\begin{array}{l}\text { Knowledge of } \\
\text { the method }\end{array}$} & Semester & $\mathrm{N}$ & range & \multicolumn{2}{|l|}{ squared } \\
\hline & \multirow{2}{*}{$\begin{array}{l}\text { First semester } \\
\text { Second semester }\end{array}$} & 217 & 169,55 & \multirow[t]{3}{*}{75,03} & \multirow[t]{3}{*}{0,00} \\
\hline & & 220 & 267,78 & & \\
\hline & Total & 437 & & & \\
\hline \multirow[t]{3}{*}{ Workload } & First semester & 217 & 257,29 & \multirow[t]{3}{*}{41,00} & \multirow[t]{3}{*}{0,00} \\
\hline & Second semester & 220 & 181,23 & & \\
\hline & Total & 437 & & & \\
\hline \multirow{3}{*}{$\begin{array}{l}\text { Assessment } \\
\text { of the method }\end{array}$} & First semester & 217 & 166,90 & \multirow[t]{3}{*}{73,37} & \multirow[t]{3}{*}{0,00} \\
\hline & Second semester & 220 & 270,39 & & \\
\hline & Total & 437 & & & \\
\hline \multirow{3}{*}{$\begin{array}{l}\text { Continuity in } \\
\text { the study }\end{array}$} & First semester & 217 & 186,72 & \multirow[t]{3}{*}{30,28} & \multirow[t]{3}{*}{0,00} \\
\hline & Second semester & 220 & 250,84 & & \\
\hline & Total & 437 & & & \\
\hline \multicolumn{6}{|l|}{300} \\
\hline \\
\hline & & & & & \\
\hline \multirow{2}{*}{\multicolumn{2}{|c|}{$0 \longdiv { \begin{array} { c } { \text { KNOWLEDGE OF THE } } \\
{ \text { METHOD } } \end{array} }$}} & WORKLOAD & $\begin{array}{r}\text { ASSESSM } \\
\text { ME }\end{array}$ & $\begin{array}{l}\text { T OF THE C } \\
\text { OD }\end{array}$ & \multirow[t]{2}{*}{$\begin{array}{l}\text { STINUITY IN THE } \\
\text { STUDY }\end{array}$} \\
\hline & & ster & Second semes & & \\
\hline
\end{tabular}

Graph 5. Average range for the four variables of the surveys

The appreciation that students have for both semesters has been analyzed in a more specific way for a) the workload of the weekly, semester and final exercises; and b) the assessment of the pedagogical method 
adopted in the class and in the performance of the weekly and semesterlong exercises.

Table 8 shows that the workload ranges from 257.29 in the first semester to 181.23 in the second. This decrease in the appreciation of the students is mainly due to the final test, as it can be seen in graph 6, remaining similar in both the weekly and the semester-long exercises. That is explained as a logical consequence of taking the course to date.
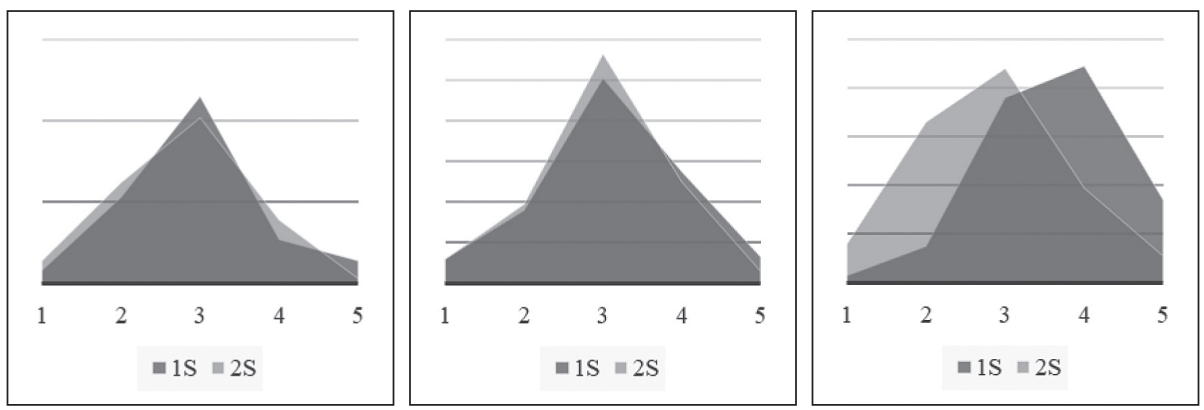

Graph 6. Workload for: a) weekly exercises, b) semester-long exercise, c) final test (Likert scale where $1=$ not much, $2=$ little, $3=$ somewhat, $4=$ much y $5=$ a great deal)

Regarding the evaluation of the pedagogical method, Graph 7 shows how there is hardly any difference between the two semesters for the class. But there is an improvement in the weekly and the semester-long exercises. This improvement in the weekly exercises is due on the one hand to the dynamics of working in groups, proposing cooperative solutions and generating a climate of team thinking, helped by the inclusion of the digital board ( $72 \%$ of students valued it positively). On the other hand, thanks to the motivation achieved by the leaderboard and the badges (74\% of the students value it positively). The semester-long exercise was considered: the improvement reached in the second semester can be explained due to the overcoming levels in the game-exercise and the classification table, where the evolution and position of each group could be appreciated graphically. That supposed a strong motivation based on the competitiveness, leading to better performance and greater satisfaction of the student. Moreover, seeing that other students had earned certain badges and had thus carried out specific activities, provided a social validation that these activities were worthwhile. It is called Social Comparison Theory (Cialdini, 2001; Festinger, 1954; Morgan, Cialdini, Hill, \& Duarte, 2017). 

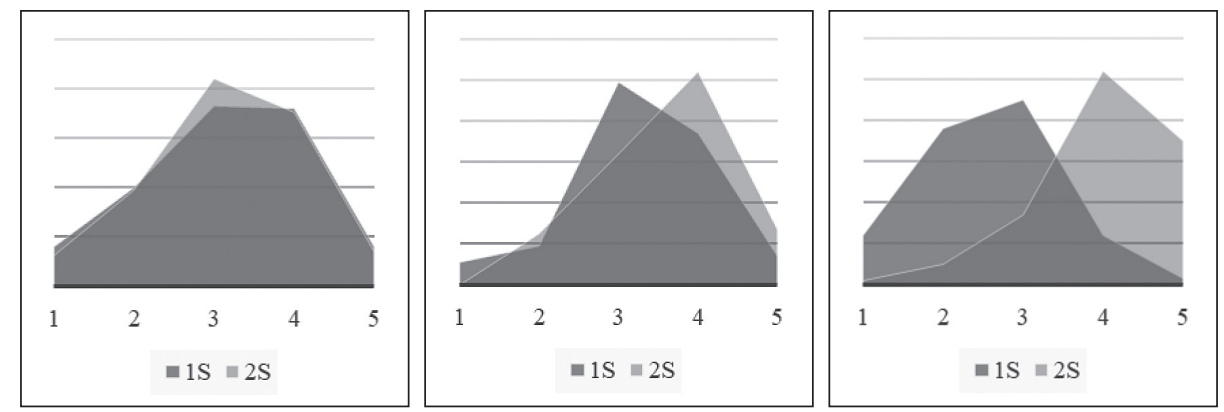

Graph 7. Assessment of the method for: a) the class, b) weekly exercises, c) semesterlong exercise (Likert scale where 1 =poor, 2 =fair, 3 =good, 4 =very good y 5 =excellent)

\section{CONCLUSIONS}

Implementation of game mechanics to the learning process of the Descriptive Geometry allowed to experiment and later to check how the students live a series of experiences that enrich their learning, providing greater attraction and motivation, learning experience, participation, and proactivity.

The experience developed during the second semester throughout three academic years had a great acceptance and an excellent result in pedagogical and academic terms. This is evident taking into account the results obtained in the courses analyzed, both considering the academic performance and withdrawal of the subject, and the data reflected in the surveys that students completed at the end of each semester. In these, the students positively assessed the new method followed in the second semester of the course. Clear descriptors of it are: the materials made to study at home, the game environment in which the tests became (without detracting from rigour), the collaborative and competitive scenario of the weekly exercises, the autonomy, mastery, and purpose of the semester-long exercise and the awareness that all this is evaluated continuously knowing the repercussion of each action in the final note.

Another expected consequence, and verified by the surveys, was the fact that the involvement of the students in their new roles as a classmateprofessor forced them to keep up; with the advantages that this implies in the advance of the subject that is built on previous concepts. In addition, this implied stimulation for the cooperative work, conferring to the students some abilities before not even raised.

On the other hand, the teaching experience was also enriched with this new pedagogical method. Motivating elements for the professor were: 
the involvement of the student that positively affected the organization and development of the lessons; the incorporation of new technologies that allowed addressing complex aspects in a more intuitive way; the new design of the program to adapt it to the objectives of the project; and finally, carrying out a continuous evaluation of the students.

In conclusion, the implementation of gamification improved the perception and experience of the university students of the subject of Descriptive Geometry, as well as the development of the professor.

Funding: This research did not receive any specific grant from funding agencies in the public, commercial, or not-for-profit sectors. 


\section{Appendix A. Rubric for the evaluation of the weekly exercises}

\begin{tabular}{|c|c|c|c|c|c|}
\hline $\begin{array}{l}\text { DOMAIN } \\
\text { LEVELS }\end{array}$ & INDICATORS & DESCRIPTO & & & \\
\hline \multirow{4}{*}{$\begin{array}{l}1 \mathrm{He} / \mathrm{she} \\
\text { understands } \\
\text { the exercise } \\
\text { and poses a } \\
\text { solution }\end{array}$} & \multirow[t]{2}{*}{$\begin{array}{l}\text { He/she places } \\
\text { the data in the } \\
\text { correct way }\end{array}$} & $\begin{array}{l}\text { He/she does } \\
\text { not place } \\
\text { anything or } \\
\text { puts it in a } \\
\text { wrong way }\end{array}$ & $\begin{array}{l}\text { He/she places } \\
\text { it without } \\
\text { foreseeing the } \\
\text { space needed } \\
\text { to develop } \\
\text { and represent } \\
\text { the solution }\end{array}$ & \multicolumn{2}{|l|}{$\begin{array}{l}\text { He/she } \\
\text { places it and } \\
\text { provides } \\
\text { the space to } \\
\text { develop the } \\
\text { exercise and } \\
\text { represent the } \\
\text { solution }\end{array}$} \\
\hline & & 0 & 0,25 & \multicolumn{2}{|l|}{0,5} \\
\hline & $\begin{array}{l}\text { He/she } \\
\text { calculates the } \\
\text { full scale of } \\
\text { the data }\end{array}$ & $\begin{array}{l}\text { He/she does } \\
\text { not calculate } \\
\text { any }\end{array}$ & $\begin{array}{l}\text { He/she } \\
\text { calculates } \\
\text { them, not } \\
\text { choosing } \\
\text { the most } \\
\text { appropriate, } \\
\text { accurate or } \\
\text { clean method }\end{array}$ & \multicolumn{2}{|l|}{$\begin{array}{l}\text { He/she } \\
\text { calculates } \\
\text { them, } \\
\text { choosing } \\
\text { the most } \\
\text { appropriate, } \\
\text { accurate and } \\
\text { clean method }\end{array}$} \\
\hline & & 0 & 0,5 & \multicolumn{2}{|l|}{1} \\
\hline \multirow{6}{*}{$\begin{array}{l}2 \mathrm{He} / \mathrm{she} \\
\text { solves the } \\
\text { geometric } \\
\text { problem }\end{array}$} & \multirow[t]{2}{*}{$\begin{array}{l}\text { He/she } \\
\text { calculates } \\
\text { necessary } \\
\text { auxiliary work } \\
\text { elements }\end{array}$} & None & $\begin{array}{l}\text { He/she only } \\
\text { defines an } \\
\text { auxiliary } \\
\text { work plane/ } \\
\text { line }\end{array}$ & $\begin{array}{l}\text { He/she only } \\
\text { defines the } \\
\text { main section } \\
\text { of the figure }\end{array}$ & $\begin{array}{l}\mathrm{He} / \mathrm{she} \\
\text { defines an } \\
\text { auxiliary } \\
\text { work plane/ } \\
\text { line and the } \\
\text { main section } \\
\text { of the figure }\end{array}$ \\
\hline & & 0 & 0,5 & 1 & 1,5 \\
\hline & \multirow[t]{2}{*}{$\begin{array}{l}\mathrm{He} / \text { she draws } \\
\text { the base of the } \\
\text { figure from } \\
\text { the previously } \\
\text { calculated } \\
\text { auxiliary } \\
\text { elements }\end{array}$} & No & $\begin{array}{l}\mathrm{He} / \text { she does } \\
\text { it through a } \\
\text { plane folding } \\
\text { or a change } \\
\text { of plane or } \\
\text { a rotation, } \\
\text { not choosing } \\
\text { the most } \\
\text { appropriate } \\
\text { one }\end{array}$ & $\begin{array}{l}\text { He/she } \\
\text { chooses } \\
\text { the most } \\
\text { appropriate, } \\
\text { accurate or } \\
\text { clean space } \\
\text { operation }\end{array}$ & $\begin{array}{l}\text { He/she } \\
\text { chooses } \\
\text { the most } \\
\text { appropriate, } \\
\text { accurate and } \\
\text { clean space } \\
\text { operation }\end{array}$ \\
\hline & & 0 & 0,5 & 1 & 2 \\
\hline & \multirow[t]{2}{*}{$\begin{array}{l}\text { He/she lifts the } \\
\text { height of the } \\
\text { figure }\end{array}$} & No & $\begin{array}{l}\text { He/she locates } \\
\text { where to } \\
\text { place the } \\
\text { height }\end{array}$ & $\begin{array}{l}\text { He/she locates } \\
\text { and measures } \\
\text { it correctly, } \\
\text { not choosing } \\
\text { the most } \\
\text { appropriate } \\
\text { method }\end{array}$ & $\begin{array}{ll}\text { He/she locates } & \mathrm{He} / \mathrm{she} \\
\text { and measures } & \text { locates and } \\
\text { it, choosing } & \text { measures } \\
\text { the most } & \text { it, choosing } \\
\text { appropriate, } & \text { the most } \\
\text { accurate or } & \text { appropriate, } \\
\text { clean method } & \text { accurate and } \\
& \text { clean method }\end{array}$ \\
\hline & & 0 & 0,5 & 1 & 1,5 \\
\hline
\end{tabular}


ANTONIO ÁLVARO-TORDESILLAS, MARTA ALONSO-RODRÍGUEZ, IRENE POZA-CASADO,

NOELIA GALVÁN-DESVAUX

GAMIFICATION EXPERIENCE IN THE SUBJECT OF DESCRIPTIVE GEOMETRY FOR ARCHITECTURE

\begin{tabular}{|c|c|c|c|c|c|c|}
\hline $\begin{array}{l}\text { DOMAIN } \\
\text { LEVELS }\end{array}$ & INDICATORS & DES & & & & \\
\hline \multirow{4}{*}{$\begin{array}{l}3 \mathrm{He} / \text { she } \\
\text { represents } \\
\text { the solution } \\
\text { correctly }\end{array}$} & \multirow{2}{*}{$\begin{array}{l}\text { He/she } \\
\text { distinguishes } \\
\text { the visible } \\
\text { parts from the } \\
\text { hidden ones }\end{array}$} & \multicolumn{2}{|l|}{ No } & \multicolumn{2}{|l|}{$\begin{array}{l}\text { Only in one } \\
\text { projection }\end{array}$} & $\begin{array}{l}\text { In both } \\
\text { projections }\end{array}$ \\
\hline & & 0 & & \multicolumn{2}{|l|}{1} & 2 \\
\hline & \multirow{2}{*}{$\begin{array}{l}\text { He/she co- } \\
\text { rrectly repre- } \\
\text { sents planes, } \\
\text { projections, } \\
\text { lines of corres- } \\
\text { pondence bet- } \\
\text { ween projec- } \\
\text { tions, ... }\end{array}$} & No & $\begin{array}{l}\text { He/she only } \\
\text { differentiates } \\
\text { one line type }\end{array}$ & $\begin{array}{l}\text { He/she } \\
\text { differentiates } \\
\text { two line types }\end{array}$ & $\begin{array}{l}\mathrm{He} / \mathrm{she} \\
\text { differentiates } \\
\text { three line } \\
\text { types }\end{array}$ & $\begin{array}{l}\mathrm{He} / \mathrm{she} \\
\text { differentiates } \\
\text { the four line } \\
\text { types }\end{array}$ \\
\hline & & 0 & 0,25 & 0,5 & 0,75 & 1 \\
\hline
\end{tabular}




\section{Appendix B. Surveys}

\section{FIRST SEMESTER}

a) Knowledge of the method (Answer: Yes/No)

- Did you know the work method that was to be followed in the course?

- And how would you be evaluated? What did each exercise count for the final grade?

- Did you know at all times your grade in the subject, where did you need to 'tighten' more to overcome it?

b) Workload (Answer: not much/little/somewhat/much/a great deal)

- How would you distribute the workload at home for the weekly exercises?

- How would you distribute the workload at home for the semester-long exercise?

- How would you distribute the workload at home for the final test?

c) Assessment of the method (Answer: Poor/Fair/Good/Very good/Excellent)

- How do you assess the pedagogical method followed in this semester for the theoretical class on the board?

- How do you assess the pedagogical method followed in this semester for the semester-long exercise at home?

- Do you think that this method supports learning objectives and competencies?

- Do you think this method promotes student participation and active learning? 
d) Continuity in the study

- When did you start studying the subject?

\section{SECOND SEMESTER}

a) Knowledge of the method (Answer: Yes/No)

- Did you know the work method that was to be followed in the course?

- And how would you be evaluated? What did each exercise count for the final grade?

— Did you know at all times your grade in the subject, where did you need to 'tighten' more to overcome it?

b) Workload (Answer: not much/little/somewhat/much/a great deal)

- How would you distribute the workload at home for the tests?

- How would you distribute the workload at home for the weekly exercises?

- How would you distribute the workload at home for the semester-long exercise?

- How would you distribute the workload at home for the final test?

c) Assessment of the method (Answer: Poor/Fair/Good/Very good/Excellent)

- How do you assess the pedagogical method followed this semester for the theoretical class (videos, Moodle, Aronson puzzle, Kahoot)?

- How do you assess the pedagogical method followed this semester for the weekly exercises in the class?

- How do you assess the pedagogical method followed this semester for the semester-long exercise in the class? 
ANTONIO ÁLVARO-TORDESILLAS, MARTA ALONSO-RODRÍGUEZ, IRENE POZA-CASADO,

- Do you think that the new technologies introduced in the classroom this semester have favoured the understanding and learning of the subject?

- Do you think that the competition generated by the leaderboard motivates the student and achieves higher levels of performance?

- Do you think the medals motivate the student and provide social validation among them?

- Do you think that this method supports learning objectives and competencies?

- Do you think this method promotes student participation and active learning?

d) Continuity in the study

- When did you start studying the subject? 
Figure captions:

- Fig1. Four levels in the execution of the semester-long exercise. In the example, the students have designed a lamp from the geometric transformation of an icosahedron

Table captions:

- Table 1. Grades and Leaderboard template. Grades board of one group in week five. It can be seen by colour columns, from left to right: weekly practices, weekly test, semester practice.

- Table 2. Work samples Students between the ages of 18 and 19.

— Table 3. Results obtained by academic year. Pearson Chi-squared test.

— Table 4. Results obtained by semester. Pearson Chi-squared test.

- Table 5. Analysis of the distribution of the results: KolmogorovSmirnov normality test.

- Table 6. Results of the Kruskal-Wallis test of the surveys per academic year.

- Table 7. Results of the Kruskal-Wallis test of the surveys per semester

Graph captions:

- Graph 1. Progress bar for each student in week 5, where they can graphically see their grade (from 0 to 10 ).

— Graph 2. Percentage of results obtained by academic year.

— Graph 3. Percentage of results obtained by semester.

- Graph 4. Percentage of students who drop out per academic year.

- Graph 5. Average range for the four variables of the surveys.

- Graph 6. Workload for: a) weekly exercises, b) semester-long exercise, c) final test (Likert scale where $1=$ not much, $2=$ little, $3=$ somewhat, $4=$ much y $5=$ a great deal). 
ANTONIO ÁLVARO-TORDESILLAS, MARTA ALONSO-RODRÍGUEZ, IRENE POZA-CASADO,

- Graph 7. Assessment of the method for a) the class, b) weekly exercises, c) semester-long exercise (Likert scale where 1=poor, 2 =fair, 3 =good, $4=$ very good y 5 =excellent). 


\section{REFERENCES}

Aronson, E., Blaney, N., Stephin, C., Sikes, J., \& Snapp, M. (1978). The Jigsaw Classroom. Beverly Hills, CA, USA: Sage Publishing Company.

Beza, O. (2011). Gamification-How games can level up our everyday life. Retrieved from https://goo.gl/Snf5FG

Buckley, P., Doyle, E., \& Doyle, S. (2017). Game On! Students' Perceptions of Gamified Learning. Journal of Educational Technology \& Society, 20(3), 1-10.

Burke, B. (2014). Gamify: How Gamification Motivates People to Do Extraordinary Things. Retrieved from https://bit.ly/2WLFWaV

Cerro Gómez, M.G. del. (2015). Aprender jugando, resolviendo: diseñando experiencias positivas de aprendizaje. XII Jornadas Internacionales de Innovación Universitaria Educar Para Transformar: Aprendizaje Experiencial, 237-244. Retrieved from http://hdl. handle.net/11268/4334

Cheong, C., Cheong, F., \& Filippou, J. (2013). Quick Quiz: A Gamified Approach for Enhancing Learning. PACIS 2013 Proceedings, 18-22. https:// doi.org/pacis2013/206

Cialdini, R. B. (2001). Influence : science and practice (4th ed.). Boston, MA, USA; Allyn and Bacon.

Csikszentmihalyi, M. (1990). Flow. In The psychology of optimal experience. New York, USA: Harper and Row.

Deterding, S., Dixon, D., Khaled, R., \& Nacke, L. (2011). From game design elements to gamefulness: Defining gamification. Proceedings of the 15th International Academic MindTrek Conference on Envisioning
Future Media Environments MindTrek '11, 9-15. https://doi. org/10.1145/2181037.2181040

Deterding, S., Khaled, R., Nacke, L. E., \& Dixon, D. (2011). Gamification: Toward a Definition. CHI EA 2011, 12-15. Retrieved from https://bit. ly/1Sg2PYp

Díaz Barriga Arceo, F., \& Hernández Rojas, G. (2010). Estrategias docentes para un aprendizaje significativo : una interpretación constructivista (3th ed.). México, México: McGraw Hill.

Dicheva, D., Dichev, C., Agre, G., \& Angelova, G. (2015). Gamification in Education: A Systematic Mapping Study. Journal of Educational Technology \& Society, 18(3), 75-88.

Domínguez, A., Saenz-de-Navarrete, J., De-Marcos, L., Fernández-Sanz, L., Pagés, C., \& Martínez-Herráiz, J.-J. (2013). Gamifying learning experiences: Practical implications and outcomes. Computers \& Education, 63, 380-392. https://doi.org/10.1016/j. compedu.2012.12.020

Elam, C., Stratton, T., \& Gibson, D. D. (2007). Welcoming a New Generation to College: The Millennial Students. Journal of College Admission, 195, 2025.

Erenli, K. (2013). The Impact of Gamification - Recommending Education Scenarios. International Journal of Emerging Technologies in Learning (IJET), 8. https://doi. org/10.3991/ijet.v8iS1.2320

Fernández-Mesa, A., Olmos-Peñuela, J., Alegre, J., \& Alegre, J. (2016). Pedagogical value of a common knowledge repository for Business Management courses. @tic. Revista 
ANTONIO ÁLVARO-TORDESILLAS, MARTA ALONSO-RODRÍGUEZ, IRENE POZA-CASADO, NOELIA GALVÁN-DESVAUX

GAMIFICATION EXPERIENCE IN THE SUBJECT OF DESCRIPTIVE GEOMETRY FOR ARCHITECTURE

d'innovació Educativa, 16, 39-47. https://doi.org/10.7203/attic.16.8044

Festinger, L. (1954). A Theory of Social Comparison Processes. Human Relations, 7(2), 117-140. https://doi. org/10.1177/001872675400700202

Fitz-Walter, Z., Johnson, D., Wyeth, P., Tjondronegoro, D., \& Scott-Parker, B. (2017). Driven to Drive? Investigating the Effect of Gamification on Learner Driver Behavior, Perceived Motivation and User Experience. Comput. Hum. Behav., 71(C), 586-595. https://doi. org/10.1016/j.chb.2016.08.050

Gardner, H. (1983). Frames of mind: the theory of multiple intelligences. New York, USA: Basic Books.

Hamari, J. (2013). Transforming homo economicus into homo ludens: A field experiment on gamification in a utilitarian peer-to-peer trading service. Electronic Commerce Research and Applications, 12(4), 236-245. https:// doi.org/10.1016/j.elerap.2013.01.004

Hamari, J. (2017). Do badges increase user activity? A field experiment on the effects of gamification. Computers in Human Behavior, 71, 469-478. https:// doi.org/10.1016/j.chb.2015.03.036

Hamari, J., \& Koivisto, J. (2014). Measuring flow in gamification: Dispositional Flow Scale-2. Computers in Human Behavior, 40, 133-143. https://doi.org/10.1016/J. CHB.2014.07.048

Hamari, J., Koivisto, J., \& Sarsa, H. (2014). Does gamification work? - A literature review of empirical studies on gamification. Proceedings of the 47th Annual Hawaii International Conference on System Sciences, 3025-3034. https://doi.org/10.1109/ HICSS.2014.377
Howe, N., \& Strauss, W. (2003). Millennials go to college: strategies for a new generation on campus : recruiting and admissions, campus life, and the classroom. Washington, DC., USA: American Association of Collegiate Registrars and Admission Offiers.

Huang, B., \& Hew, K.F. (2015). Do points, badges and leaderboards increase learning and activity: A quasi-experiment on the effects of gamification. In H. Ogata (Ed.), 23rd International Conference on Computers in Education (pp. 275-280). Pekin: China: Asia-Pacific Society for Computers in Education.

Huotari, K., \& Hamari, J. (2012). Defining Gamification - A Service Marketing Perspective. Proceeding of the 16th International Academic MindTrek Conference on - MindTrek '12, 17-22. https://doi. org/10.1145/2393132.2393137

Inge, A. (2014). Results from using various quiz-approaches in class. [blog]. Retrieved from https://bit. ly/2Z0Dw5l

Johnson, L., Smith, R., Willis, H., Levine, A., \& Haywood, K. (2011). The 2011 Horizon Report. In Media. https://doi. org/10.1002/chem.201001078

Lee, J.J., \& Hammer, J. (2011). Gamification in Education: What, How, Why Bother? Academic Exchange Quarterly, 2, 15.

Lessel, P., Altmeyer, M., \& Krüger, A. (2015). Analysis of Recycling Capabilities of Individuals and Crowds to Encourage and Educate People to Separate Their Garbage Playfully. Proceedings of the 33rd Annual ACM Conference on Human Factors in Computing Systems, 1095-1104. https:// doi.org/10.1145/2702123.2702309 
Martínez Ramón, J.P., \& Gómez Barba, F. (2010). La técnica puzzle de Aronson: descripción y desarrollo. In P. Arnaiz, M.D. Hurtado, \& F.J. Soto (Eds.), 25 Años de Integración Escolar en España: Tecnología e Inclusión en el ámbito educativo, laboral y comunitario (pp. 1-6). Retrieved from https://goo.gl/ DJy5h7

Monge, G. (1798). Géométrie descriptive. Retrieved from https:/www.e-rara.ch/ doi/10.3931/e-rara-4796

Mora, A., Riera, D., Gonzalez, C., \& Arnedo-Moreno, J. (2015). A Literature Review of Gamification Design Frameworks. 2015 7th International Conference on Games and Virtual Worlds for Serious Applications (VSGames), 1-8. https://doi.org/10.1109/ VS-GAMES.2015.7295760

Morgan, N., Cialdini, R. B., Hill, L. A., \& Duarte, N. (2017). Influence and Persuasion. Retrieved from https://bit. ly/2IlRd96

Nah, F.F.-H., Zeng, Q., Telaprolu, V. R., Ayyappa, A.P., \& Eschenbrenner, B. (2014). Gamification of Education: A Review of Literature. In F.F.-H. Nah (Ed.), HCI in Business (pp. 401409). Cham, Germany: Springer International Publishing.

Nieto Martín, S. (2000). El discurso del profesorado universitario sobre la evaluación del aprendizaje de los alumnos como estrategia de innovación y cambio profesional. Revista de Educación, 322, 305-324.

Pink, D.H. (2009). Drive: the surprising truth about what motivates us. New York, USA: Riverhead Books.

Prensky, M. (2007). Digital game-based learning. Retrieved from https://bit. ly/2ITEABk
Ramos-Salazar, L., \& Diego-Medrano, E. (2019). The Role of Millennial Students in Shaping the Digital Learning Culture in Higher Education. In Examining Millennials Reshaping Organizational Cultures: From Theory to Practice (p. 123). London, UK: Lexington books.

Robson, K., Plangger, K., Kietzmann, J.H., McCarthy, I., \& Pitt, L. (2015). Is it all a game? Understanding the principles of gamification. Business Horizons, 58(4), 411-420. https://doi. org/10.1016/J.BUSHOR.2015.03.006

Rodríguez-Fernández, L. (2017). Smartphones and learning: use of Kahoot in the university classroom. Revista Mediterránea de Comunicación, 8(1), 181-189. https://doi.org/10.14198/ MEDCOM2017.8.1.13

Santamaría González, F. (2013). La gamificación: las mecánicas del juego en los procesos de aprendizaje. Retrieved from https://goo.gl/2wQmYf

Thomas, H., \& Cornuel, E. (2012). Business schools in transition? Issues of impact, legitimacy, capabilities and re-invention. Journal of Management Development, 31(4), 329-335. https:// doi.org/10.1108/02621711211219095

Thompson, C. (2011, July). How Khan Academy is changing the rules of education. Wired Magazine, 125, 1-5.

Viñas, M. (2011). La sorprendente verdad sobre lo que motiva a tus alumnos. Recursos TIC para profesores. Retrieved from https://goo. $\mathrm{gl} / \mathrm{PrQxEBW}$

Zhu, T., Wang, B., \& Zyda, M. (2018). Exploring the similarity between game events for game level analysis and generation. Proceedings of the 13th International Conference on the Foundations of Digital Games - FDG '18, 1-7. https://doi. org/10.1145/3235765.3235804 


\section{PERFIL ACADÉMICO Y PROFESIONAL DE LOS AUTORES}

Antonio Álvaro-Tordesillas (ORCID: 0000-0002-9484-9966). Arquitecto por la ETS Arquitectura de la Universidad de Valladolid (1999). Doctor Arquitecto (2008), Profesor Contratado Doctor de Geometría Descriptiva, en el área de Expresión Gráfica Arquitectónica, Departamento de Urbanismo y Representación de la Arquitectura de la ETS Arquitectura de Valladolid. Miembro del GIR Documentación, análisis y representación del patrimonio arquitectónico (U. Valladolid) y del GIR Pensamiento gráfico y narrativa arquitectónica (U. Alicante). Profesor en cursos de Doctorado, Máster y Posgrado en otras universidades de España e Italia.

Marta Alonso-Rodríguez (ORCID: 0000-0001-7662-4213). Profesora Asociada del Departamento de Expresión Gráfica Arquitectónica en la Universidad de Valladolid (2013), Doctora por esta misma Universidad, con la tesis titulada Oviedo: Forma Urbis, restitución infográfica del patrimonio urbano perdido. Ha sido Profesora Asociada en el departamento de Arquitectura de la Universidad Antonio Nebrija de Madrid (2017-2019). Durante sus años de investigación ha orientado su labor en la aplicación de los nuevos medios informáticos para la restitución y difusión del patrimonio arquitectónico.

Irene Poza-Casado (ORCID: 0000-0002-6692-5917). Arquitecta por la ETS Arquitectura de la Universidad de Valladolid (2014) y Máster en Profesor de Educación Secundaria por la Universidad de Salamanca (2015). Actualmente, investigadora predoctoral en formación contratada por la Universidad de Valladolid en el Departamento de Construcciones Arquitectónicas, IT y MMC y TE. Participante en varios proyectos de investigación. Miembro asociado del GIR Arquitectura \& Energía.

Noelia Galván-Desvaux (ORCID: 0000-0001-9421-5851). Arquitecto por la ETS de Arquitectura de la Universidad de Valladolid (2003) y Doctor por la misma universidad (2012). Profesora Ayudante Doctor en el Área de la Expresión Gráfica Arquitectónica del Departamento de Urbanismo y Representación de la Arquitectura (ETSAVA) desde 2004. Miembro del GIR Documentación, análisis y representación del patrimonio arquitectónico (U. Valladolid) y del GIR Pensamiento gráfico y narrativa arquitectónica (U. Alicante). Profesora en cursos de Doctorado, Máster y Posgrado en España e Italia. 
Dirección de los autores: ETS Arquitectura

Universidad de Valladolid

Avda. Salamanca 18

47014 - Valladolid

E-mail: tordesillas@arq.uva.es

marta.alonso.rodriguez@uva.es

irene.poza@uva.es

noeliagalvan@arq.uva.es

Fecha Recepción del Artículo: 25. Enero. 2019

Fecha Modificación del Artículo: 19. Junio. 2019

Fecha Aceptación del Artículo: 01. Julio. 2019

Fecha Revisión para Publicación: 10. Julio. 2019 